Rev. Inst. Flor. v. 26 n. 2 p. 203-213 dez. 2014

http://dx.doi.org/10.4322/rif.2014.016

ISSN impresso 0103-2674/on-line 2178-5031

\title{
THE INFLUENCE OF ABIOTIC FACTORS ON LITTER DEPOSITION IN A SEMIARID AREA, NORTHEASTERN BRAZIL ${ }^{1}$
}

\section{INFLUÊNCIA DE FATORES ABIÓTICOS NA DEPOSIÇÃO DE SERAPILHEIRA EM UMA ÁREA SEMIÁRIDA NO NORDESTE BRASILEIRO}

\author{
Ivan Jeferson Sampaio DIOGO ${ }^{2,6}$; Irlaine Rodrigues VIEIRA ${ }^{3}$; \\ Andréa Pereira SILVEIRA ${ }^{4}$; Francisca Soares de ARAÚJJO ${ }^{5}$
}

\begin{abstract}
The amount of deciduous material throughout the year is mostly related to climatic conditions in tropical areas. A large deposition of litterfall in the dry season is described for deciduous and semideciduous forests. We aimed to assess the monthly deposition rate of litterfall during one year and the climatic influence in a deciduous thorny woodland area. The study area had a permanent plot of one hectare. To collect litterfall, 50 plots were selected and a collector $(0.5 \times 0.5 \mathrm{~m})$ was installed. Samples were collected monthly for twelve months and divided into fractions: leaves, branches, fruits and seeds, flowers and miscellaneous. We tested the correlation of four abiotic factors (rainfall, soil humidity, temperature and wind) and the litter deposition.The annual litterfall collected had a total value of $2,731.6 \mathrm{~kg} \mathrm{ha}^{-1}$.The contribution fraction of leaves corresponded to $54.3 \%$, branches $(14.2 \%)$, fruits $(12.6 \%)$, flowers $(1.6 \%)$ and miscellaneous $(17.2 \%)$. The wind was the abiotic factor most correlated with the total deposition of the litterfall, but other correlations were found. In this area, site-dependent climatic and edaphic variables have an important control on litterfall.
\end{abstract}

Keywords: deciduousness; weather; environmental factors; Caatinga.

RESUMO - A quantidade de material decíduo ao longo do ano em ambientes tropicais está relacionada principalmente com as condições climáticas. Há uma grande deposição de serapilheira na estação seca em florestas decíduas e semidecíduas. Este trabalho teve como objetivo avaliar a taxa de deposição mensal de serapilheira durante um ano e a influência climática sobre esta deposição em uma área de floresta decídua espinhosa. A área de estudo teve uma parcela permanente de um hectare. Para a coleta de serapilheira, foram selecionados 50 pontos e um coletor $(0,5 \times 0,5 \mathrm{~m})$ foi instalado. As amostras foram coletadas mensalmente, por doze meses, e divididas em cinco frações: folhas, galhos, frutos e sementes, flores e miscelânea. Foi testada a correlação entre quatro fatores abióticos (pluviosidade, umidade do solo, temperatura e vento) e a deposição de serapilheira. Obteve-se um valor total de $2.731,6 \mathrm{~kg} \mathrm{ha}^{-1}$ no período de coleta. A contribuição da fração folhas correspondeu a $54,3 \%$, ramos $(14,2 \%)$, frutos $(12,6 \%)$, flores $(1,6 \%)$ e miscelânea $(17,2 \%)$. Embora a velocidade do vento tenha sido o fator abiótico mais correlacionado com a deposição total de serapilheira, outras correlações foram encontradas. Variáveis climáticas e edáficas têm um controle importante na produção de serapilheira nesse ambiente.

Palavras-chave: deciduidade; tempo; fatores ambientais; Caatinga.

\footnotetext{
1Received for analysis on 20.05.14. Accepted for publication on 11.12.14.

2Programa de Pós-Graduação em Biologia Vegetal, Universidade Estadual de Campinas, Instituto de Biologia, Departamento de Botânica, Rua Monteiro Lobato, 255, 13083-970 Campinas, SP, Brasil.

${ }^{3}$ Programa de Pós-Graduação em Desenvolvimento e Meio Ambiente, Universidade Federal do Piauí - UFPI, Campus Ministro Reis Veloso, Av. São Sebastião, 2819, 64202-020 Parnaíba, PI, Brasil.

${ }^{4}$ Universidade Estadual do Ceará, Faculdade de Educação de Itapipoca, FACEDI/UECE, Rua da Universidade, s/n, Coqueiro, $62500-000$ Itapipoca, CE, Brasil. ${ }^{5}$ Universidade Federal do Ceará - UFC, Centro de Ciências, Departamento de Biologia, Av. Mister Hull, s/n, Campus do Pici, Bloco 906, 60455-760 Fortaleza, CE, Brasil.

${ }^{6}$ Corresponding author: Ivan Jeferson Sampaio Diogo - ivan_kdf@yahoo.com.br
} 


\section{INTRODUCTION}

Litterfall is a key process in nutrient cycling of forest ecosystems (Baker et al., 2004; Isaac and Nair, 2006) and plays a fundamental role in nutrient turnover and in the transfer of energy between plants and soil (González-Rodríguez et al., 2011). Litterfall deposition provides valuable information on the productivity and dynamics of nutrient cycling in forest ecosystems (Navarro et al., 2013). However, the inputs vary among forest ecosystems in terms of quality (Duchesne et al., 2001; Vasconcelos and Luizão, 2004) and quantity (Rothe and Binkley, 2001; Zhou et al., 2007).

It is widely assumed that the amount and quality of litterfall depend on climate (Meentemeyer et al., 1982; Albrektson, 1988; Berg and Meentemeyer, 2001) and influence the heterogeneity of soil conditions and the distribution of species in a plant community (Facelli and Pickett, 1991; Austin et al., 2004; Hooker and Stark, 2008). These effects can be altered at a regional scale by climate and soil factors, such as altitude, soil type, nutrient, water availability, humidity, temperature, seasonality and wind according to the study area (Lodhiyal and Lodhiyal, 2002; Li et al., 2006; Martínez-Alonso et al., 2007).

Based on data from studies conducted in different macroecological zones, the amount of deciduous material throughout the year is mostly related to climatic conditions, higher in hot and humid tropical areas (Bray and Gorham, 1964). Each ecosystem has its particular type of deposition and nutrient cycling. The deposition of litterfall during the seasons is quite variable for different forest formations in tropical zone (Spain, 1984; Chave et al., 2010).

In dry areas, a large deposition of litterfall in the dry season is described in comparison with wet season (Lodhiyal and Lodhiyal, 2002; Jha and Mohapatra, 2010; Alvarez, 2009; McIvor, 2001). In these forest formations, litterfall deposition coincides with the period of water-limitation, which does not imply the cessation of nutrient cycling, although it is reduced to $1 / 4$ of the total (Delitti, 1995).

Increased understanding of the climate variables that govern the deposition of litterfall in drylands will help to further elucidate how plant biomass is accumulated in these ecosystems and will provide a better understanding of the processes that relate to nutrient cycling, calcination process and soil formation. Our general hypothesis was that litterfall is directly influenced by abiotic factors. To test this hypothesis, we focused on the deposition of dead plant biomass and the influence of some abiotic/climatic variables in a semiarid and well-preserved area of deciduous thorny woodland.

We aimed to assess the monthly deposition rate of litterfall during one year and the climatic influence. We hypothesized that (1) most of the deposition occurs between the end of the rainy season and the beginning of the dry season that coincides with the plant water stress, (2) leaves are the main monthly contributor to biomass production because of the deciduousness and (3) rainfall and soil humidity are the climate factors that have more influence on deposition.

\section{MATERIAL AND METHODS}

This study was conducted in deciduous thorny woodland, locally known as Caatinga (Woodward et al., 2004). The area is inside the Serra das Almas Natural Reserve, in Crateús (5'10'58.1'S and $40^{\circ} 40^{\prime} 19.4$ ' $\mathrm{W}$ ), central-west region of the state of Ceará, Brazil, at an altitude of $297 \mathrm{~m}$ asl.

The regional climate is classified as BSh (hot semiarid, with rainy summer and dry winter) in the Köppen-Geiger system (Peel et al., 2007). The average annual rainfall in the Caatinga of Crateús is $683 \mathrm{~mm}$, and, even though it has well-defined rainy and dry seasons, the total annual rainfall is variable between years.

Due to this rainfall variability, we used the climate diagram of Walter and Lieth (Figure 1) to demonstrate the extent of dry and rainy seasons in the years 2009 (rainy season: January to May and dry season: from June to December) and 2010 (rainy season: January to April with a drought interpulse in February, and the dry season: May to November). The average annual temperature is $27^{\circ} \mathrm{C}$. 

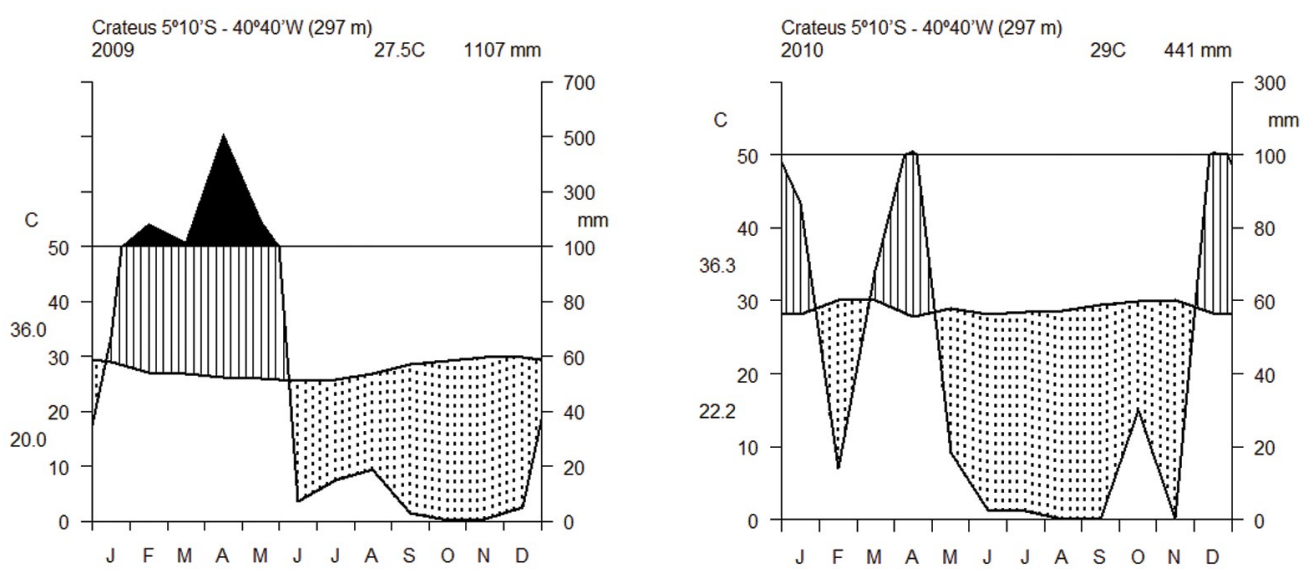

Figure 1. Climatic diagram Walter and Lieth (temperature and rainfall $\mathrm{x}$ months), during the study period (2009-2010) for Crateús. R environment, package climatol (R Development Core Team, 2010).

Figura 1. Diagrama climático Walter \& Lieth (temperatura e precipitação x meses) durante o período de estudo (2009-2010) para Crateús. Programa R (R Development Core Team, 2010).

The plant community of the area was formed by 25 species belonging to 14 families and 21 genera. Fabaceae ( 9 species), Euphorbiaceae (3) and Apocynaceae (2) were the families with greater richness. Fabaceae was the most numerous $(875$ individuals divided into subfamilies Caesalpinioidae: 84; Cercidae: 124; Faboidae: 13 and Mimosoidae: 654) followed by Euphorbiaceae (511) and Boraginaceae (195). Aspidosperma, Croton, Caesalpinia and Mimosa were the only genera that occurred with more than one species (Menezes, 2010).

To evaluate species composition of the seed rain in this area, we established ten transects perpendicular to the matrix forest, separated from each other by $10 \mathrm{~m}$. Along pair transects, we placed seed traps starting at $20 \mathrm{~m}$ distance from the matrix forest and with $20 \mathrm{~m}$ intervals $(20,40,60,80$ and $100 \mathrm{~m}$ ), while odd transects had seed traps starting at $10 \mathrm{~m}$ distance from the matrix forest and with $20 \mathrm{~m}$ intervals from the matrix forest $(10,30,50$, 70 and $90 \mathrm{~m}$ ), yielding five traps per transect and 50 overall. Each trap consisted of a square polyethylene bucket of $0.5 \mathrm{~m}^{2}$ and $20 \mathrm{~cm}$ high. They were placed directly on the ground and fixed with wooden stakes. A layer of grease was applied around the edge of each trap to prevent seed predation. Small holes were made in trap sides to avoid rainwater accumulation and subsequent seed decay (Zimmerman et al., 2000; Cubina and Aide, 2001).
Samples were collected monthly for twelve months (June/2009 - May/2010), closing the annual cycle of monitoring the production of plant biomass (dry and rainy season). The collected material was sorted and separated into reproductive material, vegetative and inert, and divided into the following fractions: 1) mature, immature, and predated fruits and seeds that fall separately of the fruits, 2) flowers and inflorescences, 3) leaves, 4) branches (stems and petioles) and 5) miscellaneous, corresponding to residues and animal droppings, soil, seeds of herbaceous, small leaves (Backes et al., 2005). The material was put to dry in air for further screening.

The screened material was taken to the oven at $65{ }^{\circ} \mathrm{C}$ and weighed on a precision scale with three decimal places until constant weight to evaluate the monthly and annual production of litterfall and the contribution of each of the fractions in the litterfall.

We estimated the monthly and annual biomass $\left(\mathrm{kg} \mathrm{ha}^{-1}\right)$ by the average amount of litterfall found in the traps. First, data were tested for normality using the Shapiro-Wilk test $(p>0.05)$. Then, we carried out analyses of variance (ANOVA) to observe statistical differences between litterfall in each month and litterfall for each fraction with significance levels of $5 \%$ using the Tukey's test. 
In order to assess which of the abiotic factors (rainfall, soil humidity, temperature and wind) were correlated with the deposition of litterfall, the relationship between abiotic factors in the month of deposition of the litterfall and in the previous month to the event with each fractions of litterfall was analyzed using a Spearman correlation test (rs).

Data for rainfall and temperature were obtained from the climatological station of the Instituto Nacional de Meteorologia - INMET (National Institute of Meteorology) (2010), located in the city of Crateús, $25 \mathrm{~km}$ away from the study area and at a similar altitude. Data for wind speed were obtained from Fundação Cearense de Meteorologia e Recursos Hídricos - FUNCEME (Ceará Foundation of Meteorology and Water Resources) (2010) and soil humidity data were obtained from Silveira et al. (2013).

\section{RESULTS}

Annual litterfall collected had a total value of 2,731.6 kg ha-1 (Table 1). The months of August and September/2009 diverged from the other months, since they showed the highest rates of litter input and the lowest rate was in December/2009, differing from the other months (Figure 2). The seasonality in the input of litterfall occurred due to the fact that dry season was responsible for the investment of 2,015.323 kg ha-1, $73.8 \%$ of the total contribution; consequently, the lowest litterfall was in the rainy season. However, the months of February/2010 and April/2010 showed high rates of deposition of litter compared to other months of the rainy season (Figure 2).

Table 1. Litterfall production $\left(\mathrm{kg} \mathrm{ha}^{-1}\right)$ in the study period.

Tabela 1. Produção de serapilheira $\left(\mathrm{kg} \mathrm{ha}^{-1}\right)$ no período de estudo.

\begin{tabular}{lcccccc}
\hline & Leaves & Branches & Fruits & Flowers & Miscellaneous & Total \\
\hline June/2009 & 39.300 & 9.360 & 15.580 & 0 & 42.700 & 106.940 \\
July/2009 & 93.847 & 14.217 & 12.600 & 0 & 37.404 & 158.069 \\
August/2009 & 589.486 & 68.281 & 138.354 & 0.608 & 130.800 & 927.528 \\
September/2009 & 276.498 & 32.250 & 42.465 & 4.370 & 40.635 & 396.218 \\
October/2009 & 216.541 & 26.756 & 26.029 & 0.591 & 20.243 & 290.160 \\
November/2009 & 34.967 & 16.168 & 22.661 & 5.150 & 7.731 & 86.678 \\
December/2009 & 16.359 & 7.276 & 16.932 & 5.796 & 3.368 & 49.731 \\
January/2010 & 18.194 & 11.618 & 26.456 & 0.676 & 56.892 & 113.836 \\
February/2010 & 40.092 & 108.407 & 18.604 & 10.405 & 25.206 & 202.714 \\
March/2010 & 57.827 & 16.330 & 10.268 & 0.854 & 24.587 & 109.866 \\
April/2010 & 60.887 & 69.465 & 12.610 & 0.815 & 54.940 & 198.718 \\
May/2010 & 39.148 & 7.791 & 2.633 & 16.490 & 25.075 & 91.136 \\
Average & $123.596 \mathrm{a}$ & $32.327 \mathrm{~b}$ & $28.766 \mathrm{~b}$ & $3.812 \mathrm{c}$ & $39.132 \mathrm{~b}$ & 227.633 \\
& \pm 167.844 & \pm 32.364 & \pm 35.944 & \pm 5.113 & \pm 33.318 & \pm 241.212 \\
Total Annual & 1483.146 & 387.919 & 345.193 & 45.754 & 469.581 & 2731.594 \\
& $(54.3 \%)$ & $(14.2 \%)$ & $(12.6 \%)$ & $(1.7 \%)$ & $(17.2 \%)$ & $(100 \%)$ \\
\hline
\end{tabular}

*The average results followed by same letter do not differ according to the Tukey's test $(\mathrm{p}<0.05)$.

*Médias seguidas de mesma letra não diferem de acordo com o teste de Tukey $(\mathrm{p}<0,05)$. 
DIOGO, I.J.S. et al. Litter $v s$. abiotic factors in Brazilian semiarid

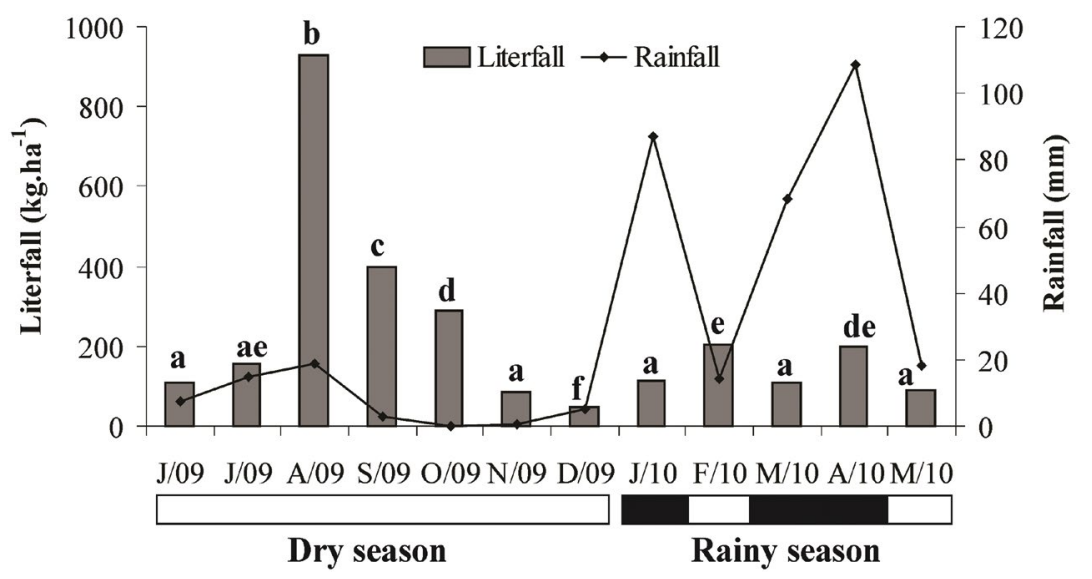

Figure 2. Litterfall $\left(\mathrm{kg} \mathrm{ha}^{-1}\right)$ produced per month compared to average rainfall $(\mathrm{mm})$ recorded in the period from June/2009 to May/2010. Months followed by the same letter do not differ according to the Tukey's test $(p<0.05)$. In the rainy season, the months with pulses of rain are represented by dark areas, and the dry months, by white areas.

Figura 2. Serapilheira $\left(\mathrm{kg} \mathrm{ha}^{-1}\right)$ produzida por mês em relação à precipitação média $(\mathrm{mm})$ registrada no período de junho/2009 a maio/2010. Meses seguidos pela mesma letra não diferem de acordo com o teste de Tukey $(\mathrm{p}<0,05)$. $\mathrm{Na}$ estação chuvosa, os meses com pulsos de chuva são representados por áreas escuras, e os meses de seca, por áreas brancas.

The contribution fraction of leaves corresponded to $54.3 \%$ of all deposited material, differing from the other fractions (Table 1) and had a positive correlation with the total litterfall $(\mathrm{rs}=0.935, \mathrm{p}<0.05)$. There was a greater deposition of leaves in August, September and October/2009 (Figure 3), which is directly reflected in higher deposition of total litterfall in those months (Figure 2). The smaller contribution of leaves occurred in the months of November/2009 and December/2009, end of the dry season, and January/2010, beginning of the rainy season (Figure 3).
The miscellaneous fraction represented $17.2 \%$ of total litter and the second largest contribution, not differing statistically with the fractions of branches and fruits (Table 1). August/2009 was the month with the highest amount of miscellany. The months of January/2010 and April/2010 showed a relative increase in the rate of miscellaneous material with the highest average monthly rainfall. In November/2009 and December/2009, miscellaneous rates were relatively low when compared to other months, when rates were nearly uniform (Figure 3 ).

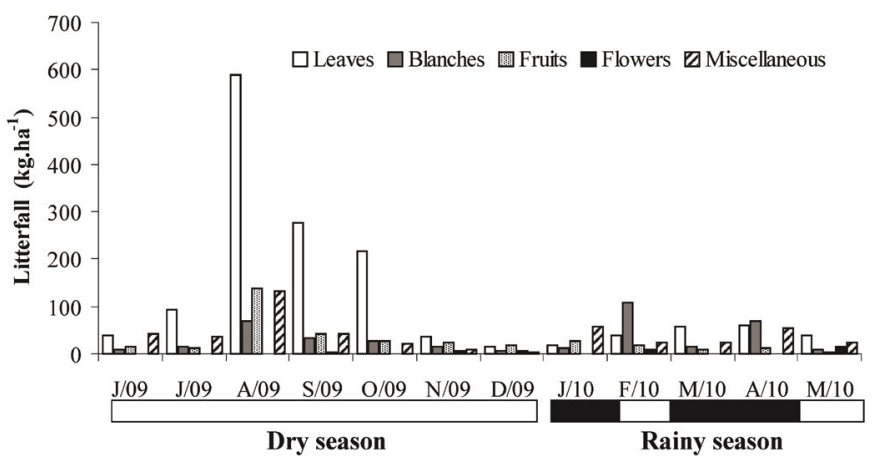

Figure 3. Production of litterfall of each fraction $\left(\mathrm{kg} \mathrm{ha}^{-1}\right)$ from June/2009 to May/2010. In the rainy season, the months with pulses of rain are represented by dark areas, and the dry months, by white areas.

Figura 3. Produção de serapilheira de cada fração $\left(\mathrm{kg} \mathrm{ha}^{-1}\right)$ de junho/2009 a maio/2010. Na estação chuvosa, os meses com pulsos de chuva são representados por áreas escuras, e os meses secos, por áreas brancas. 
From the total, $14.2 \%$ corresponded to the fraction of branches. Although there is a temporality correlation between the deciduousness of leaves and branches with overlaps, the greater amount of branches in February/2010 and April/2010 leads to a major contribution in the rainy season (Figure 3).

The fruit fraction corresponded to $12.6 \%$ of total deposition. Although this fraction has shown a low percentage of the total number of litter produced, it is observed that the distribution was uniform throughout the year, except for the highest peak contribution in August/2009 (Figure 3), occurred due to the high rates of wind speed in this month (Table 2).

The fraction of flowers differed significantly when compared to other fractions, because they contributed only with $1.7 \%$ (Table 1 ). The months with highest deposition of flowers were February/2010 and May/2010 (Figure 3).
The climatic data showed the biggest rainfall in January and April/2010, low annual temperature variation from $24.8{ }^{\circ} \mathrm{C}$ in the coldest month (June/09) to $29.5{ }^{\circ} \mathrm{C}$ in the warmest month (November/2009), big variation of soil humidity from 3.2\% (December/2009) to 12.3\% (June/2009) and months with great wind velocity (August/2009 and February/2010) (Table 2).

The wind was the only abiotic factor that was correlated with the total deposition of the litterfall, the amount of litter increased with increasing wind speed. The fractions of leaves, branches and fruits were also positively correlated with the wind speed in the month of deposition. Branches had the highest correlation (Table 3).

The deposition of flowers was positively correlated with temperature. Miscellaneous were positively correlated with precipitation and soil moisture and negatively with temperature. Lastly, leaves were negatively correlated with temperature (Table 3).

Table 2. Climatic data per month for the Caatinga studied area.

Tabela 2. Dados climáticos por mês para a área estudada.

\begin{tabular}{lcccc}
\hline & $\begin{array}{c}\text { Rainfall } \\
\mathrm{mm}\end{array}$ & $\begin{array}{c}\text { Temperature } \\
\left({ }^{\circ} \mathrm{C}\right)\end{array}$ & $\begin{array}{c}\text { Soil humidity } \\
(\%)\end{array}$ & $\begin{array}{c}\text { Wind velocity } \\
(\mathrm{km} / \mathrm{h})\end{array}$ \\
\hline June/2009 & 7.3 & 24.8 & 12.3 & 13 \\
July/2009 & 14.8 & 25.0 & 7.9 & 15 \\
August/2009 & 18.6 & 26.2 & 4.1 & 21 \\
September/2009 & 2.7 & 28.0 & 3.7 & 17 \\
October/2009 & 0.2 & 29.1 & 3.8 & 17 \\
November/2009 & 0.6 & 29.5 & 3.7 & 15 \\
December/2009 & 5.0 & 29.3 & 3.2 & 13 \\
January/2010 & 86.8 & 27.4 & 11.1 & 14 \\
February/2010 & 14.1 & 29.3 & 3.1 & 23 \\
March/2010 & 68.4 & 29.2 & 4.6 & 13 \\
April/2010 & 108.9 & 27.0 & 16.1 & 19 \\
May/2010 & 18.4 & 28.0 & 6.9 & 11 \\
\hline
\end{tabular}


DIOGO, I.J.S. et al. Litter vs. abiotic factors in Brazilian semiarid

Table 3. Spearman correlations (rs) between the abiotic factors and the fractions of litterfall.

Tabela 3. Correlações de Spearman (rs) entre os fatores abióticos e as frações de serapilheira.

\begin{tabular}{lcccccccc}
\hline Fractions & $\mathrm{R} 0$ & $\mathrm{R} 1$ & $\mathrm{H} 0$ & $\mathrm{H} 1$ & $\mathrm{~T} 0$ & $\mathrm{~T} 1$ & $\mathrm{~W} 0$ & $\mathrm{~W} 1$ \\
\hline Total litter & 0.08 & 0.22 & -0.05 & 0.06 & -0.32 & -0.46 & $0.80^{*}$ & -0.13 \\
Leaves & -0.01 & 0.22 & 0.04 & 0.16 & -0.39 & $-0.61^{*}$ & $0.61^{*}$ & 0.11 \\
Branches & 0.13 & 0.19 & -0.18 & -0.02 & 0.05 & -0.17 & $0.91^{*}$ & -0.14 \\
Flowers & -0.06 & 0.05 & -0.56 & -0.09 & $0.73^{*}$ & 0.41 & -0.12 & 0.28 \\
Fruits & -0.30 & -0.31 & -0.37 & -0.27 & 0.05 & -0.09 & $0.57^{*}$ & -0.11 \\
Miscellaneous & $0.61^{*}$ & 0.49 & $0.58^{*}$ & 0.31 & $-0.78^{*}$ & -0.42 & 0.36 & -0.41 \\
\hline
\end{tabular}

$\mathrm{R}=$ rainfall; $\mathrm{H}=$ soil humidity; $\mathrm{T}=$ temperature; $\mathrm{W}=$ wind speed; $0=$ month of deposition of the litterfall, and $1=$ month previous to the occurrence of the deposition of the litterfall. * Significant results $(\mathrm{p}<0.05)$.

$\mathrm{R}=$ pluviosidade; $\mathrm{H}$ = umidade do solo; $\mathrm{T}$ = temperatura; $\mathrm{W}=$ velocidade do vento; 0 = mês de deposição da serapilheira, e 1 = mês anterior à deposição de serapilheira. * Resultados significativos $(\mathrm{p}<0,05)$.

\section{DISCUSSION}

\section{When most of the deposition of the litterfall occurs?}

Contrary to our first hypothesis, we found the highest rates of litter input concentrated at three months of the dry season. While in the rainy season of Serra das Almas Natural Reserve, the forest is predominantly herbaceous, consisting of mainly therophytes and a woody component with approximately 25 species per hectare; in the dry season, the herbaceous plants die and most trees and shrubs lose their leaves (Araújo et al., 2011; Costa and Araújo, 2012).

The deciduous behavior of most species of Caatinga explains the lower deposition rate at the end of the dry season and the beginning of the rainy season. The lowest rate in December can be explained by the small amount of edaphic moisture. While, high rates in February and April can be associated with the intense wind velocity.

The value found for total litterfall is expected for Caatinga areas, where the average litter production is between 1,500 and 3,000 kg ha-1. year (Costa et al., 2007; Andrade et al., 2008). This production is small when compared to Brazilian rainforests (Freire, 2006; Santana et al., 2003). Furthermore, there is no great accumulation of litter in the semiarid areas, because the volume produced is not significant even when compared to rainforests and the calcination occurs (Montès et al., 2002).
This strong concentration of calcium probably participates in the neutralisation of top soil (Gauquelin et al., 1998) through litterfall. Because of the major contribution of calcium in leaves, branches, branchlets and trunks, the calcination of litterfall roughly cancels its contribution to nutrient cycling, where the soils of semiarids areas have important participation as source of nutrients (Montès et al., 2002).

\section{Which fraction is the main monthly contributor to biomass production?}

Corroborating our second hypothesis, the higher deposition of leaves is a seasonal process of gradual replacement of structures in adults by new leaves and occurs due to the small longevity of the leaves compared to other plant organs. The highest deposition of leaf litterfall in the beginning of the dry season represents a plant community response to the intense dry period, where leaf fall is a preventive measure or physiological adaptation to water stress due to the higher levels of abscisic acid (Sundarapandian and Swamy, 1999).

The smaller contribution of leaves that occurred in November, December and January can be related with the end of the dry season, where the majority of species have already lost their leaves, and the beginning of the rainy season, where there is the renewing of leaves. 
The increase in water supply, which is quite limited in semiarid regions, leads to a renewing of leaves (Monasterio and Sarmiento, 1976; Shipley and Meziane, 2002).

Although there is a synchrony in leaf deposition and water loss, with higher deposition during periods of reduced precipitation, the leaves are not shed or flushed only in response to variation in rainfall. The annual rainfall in tropical forests indirectly affects leaf litter production and there is no simple relationship between the variables (Proctor et al., 1983). There is variability in the time of leaf abscission and in the presence or absence of correlation between rainfall and leaf fall for Caatinga species (Lima and Rodal, 2010), since they have different sensitivities to water stress.

The increased supply of food for insects and birds in the rainy season, as well as the competition for food between them, contributes to a greater deposition of excreta and parts of dead insects which make up the miscellaneous fraction (Santos et al., 2011). Miscellaneous is directly correlated with decreasing temperature, which is responsible for enhancing the metabolic activity of animals, generating a greater amount of excrement. The low rates of miscellaneous at the end of the dry season and beginning of the rainy season are related to the reduction of green matter to be consumed by insects, since most species undergo shedding during the dry season.

The fall of branches can be attributed to the occurrence of adverse weather conditions. The greater deposition of this fraction in the rainy season is associated to the intensity of the wind speed that follows the rains during this period, which would be related to deterioration of wood. The uniform behavior of deposition of fruits fraction is explained by the presence of species that have different periods of fruiting in semiarid (Griz and Machado, 2001).

Although there was no correlation between flowers and rainfall, the greatest input of flowers occurred in the rainy season, since most species in the semiarid region give flowers shortly after the start of the rainy season (Borchet, 1996). There was an increment in the number of flowers available with an increase in temperature; however, there is no high temperature variation in the semiarid region.
This fact may be explained by an overlap between physiological manifestations caused by ground water level and temperature.

\section{Which climate factors have more influence on litterfall deposition?}

The high production of deciduous material at the beginning of the dry season is a result of the adaptation mechanism for semiarid species to reduce water loss during the dry period (Ferri and Labouriau, 1952). Although the importance of water for semiarid areas is widely described, rainfall and soil humidity did not present correlation with total litter, denying our third hypothesis. These climatic factors should be analyzed together, since they interact with each other and effects can be summed.

The high correlation of the increased production of litter with increasing wind speed is explained by physical strength able to pull their components down. The estimated litterfall corresponds very well to prevailing wind directions during leaf fall in a model developed for broad-leaved deciduous forest (Staelens et al., 2003). Consequently, prevailing wind directions during leaf, branch and fruit fall affected litter deposition in a Caatinga forest. Since the wind has correlation with almost all the fractions, we think that wind need to be included in ecosystem models or biogeochemical models in drylands. However, even if the wind does not have an active influence in the area, the deposition will continue to occur, so this factor should be considered as one more contribution to the deposition of litter.

In Caatinga areas, site-dependent climatic variables have an important control on litterfall. We found that the cause of the predicted ecosystem differences in terms of its contribution to litterfall is completely related to climate models in drylands. Because litter decomposition is probably linked to local forest structure as well, climate-spatial models can result in a better understanding of litter accumulation. Incorporating the influence and interaction of individual abiotic factors and insights into the heterogeneous litter input is also necessary to evaluate the efficiency of litterfall sampling strategies. 


\section{ACKNOWLEDGMENTS}

We thank Conselho Nacional de Desenvolvimento Científico e Tecnológico - CNPq (National Council for Scientific and Technological Development) for the scholarship granted to the first author for his undergraduate research. We also thank Fundação Cearense de Apoio ao Desenvolvimento Científico e Tecnológico (Ceará State Foundation for the Support to Scientific and Technological Development) (FUNCAP - Edital $05 / 2009$ ) for the subsidy to perform the field work.

\section{REFERENCES}

ALBREKTSON, A. Needle litterfall in stands of Pinus sylvestris L. in Sweden, in relation to site quality, stand age and latitude. Scandinavian Journal of Forest Research, v. 3, p. 333-343, 1988.

ALVAREZ, J.A. et al. Spatial and temporal litterfall heterogeneity generated by woody species in the Central Monte desert. Plant Ecology, v. 205, p. 295-303, 2009.

ANDRADE, R.L. et al. Deposição de serrapilheira em área de caatinga na RPPN "Fazenda Tamanduá", Santa Terezinha - PB. Revista Caatinga, v. 21, p. 223-230, 2008.

ARAÚJO, F.S. et al. Floristics and life-forms along a topographic gradient, central-western Ceará, Brazil. Rodriguésia, v. 62, n. 2, p. 341-366, 2011.

AUSTIN, A.T.; YAHDJIAN, L.; STARK, J.M. Water pulses and biogeochemical cycles in arid and semiarid ecosystems. Oecologia, v. 141, p. 221-235, 2004.

BACKES, A.; PRATES, F.L.; VIOLA, M.G. Produção de serapilheira em Floresta Ombrófila Mista, em São Francisco de Paula, Rio Grande do Sul, Brasil. Acta Botanica Brasilica, v. 19, p. 155-160, 2005.

BAKER, T.R. et al. Increasing biomass in Amazonian forest plots. Philosophical Transactions of the Royal Society B, v. 359, p. 353-365, 2004.

BERG, B.; MEENTEMEYER, V. Litter fall in some European coniferous forests as dependent on climate: a synthesis. Canadian Journal of Forest Research, v. 31, p. 292-301, 2001.
BORCHET, R. Phenology and flowering periodicity of Neotropical dry forest species: evidence from herbarium collections. Journal of Tropical Ecology, v. 12, p. 65-80, 1996.

BRAY, R.J.; GORHAN, E. Litter productions forests of the world. Advances in Ecological Research, v. 2, p. 101-157, 1964.

CHAVE, J. et al. Regional and seasonal patterns of litterfall in tropical South America. Biogeosciences, v. 7, p. 43-55, 2010.

COSTA, C.C.A. et al. Produção de serapilheira na caatinga da Floresta Nacional do Açú-RN. Revista Brasileira de Biociências, v. 5, p. 246-248, 2007.

COSTA, R.C.; ARAÚJO, F.S. Physiognomy and structure of a caatinga with Cordia oncocalyx (Boraginaceae), a new type of community in Andrade-Lima's classification of caatingas. Rodriguésia, v. 63, p. 269-276, 2012.

CUBINA, A.; AIDE, T.M. The effect of distance from forest edge on seed rain and soil seed bank in a tropical pasture. Biotropica, v. 33, n. 2, p. 260-267, 2001.

DELITTI, W.B.C. Estudos da ciclagem de nutrientes: instrumentos para análise funcional de ecossistemas terrestres. Oecologia Brasiliensis, v. 1, p. 469-486, 1995.

DUCHESNE, L. et al. Seasonal nutrient transfers by foliar resorption, leaching, and litter fall in a northern hardwood forest at Lake Clair watershed, Quebec, Canada. Canadian Journal of Forest Research, v. 31, p. 334-344, 2001.

FACELLI, J.M.; PICKETT, S.T.A. Plant litter: its dynamics and effects on plant community structure. Botanical Review, v. 57, p. 1-25, 1991.

FERRI, M.G.; LABOURIAU, L.G. Water balance of plants from "caatinga". I. Transpiration of some of the most frequent species of the "caatinga" of Paulo Afonso (Bahia) in the rainy season. Revista Brasileira de Biologia, v. 12, p. 301-312, 1952.

FREIRE, M. Chuva de sementes, banco de sementes do solo e deposição de serrapilheira como bioindicadores ambientais no bioma Mata Atlântica, Teresópolis, RJ. 2006. 69 f. Dissertação (Mestrado em Ciências) - Universidade Federal Rural do Rio de Janeiro, Seropédica. 
DIOGO, I.J.S. et al. Litter vs. abiotic factors in Brazilian semiarid

FUNDAÇÃO CEARENSE DE METEOROLOGIA E RECURSOS HÍDRICOS - FUNCEME. Monitoramento global mensal. Available at: $<$ http://www.funceme.br/index.php/areas/23monitoramento/meteorol\%C3\%B3gico/541monitoramento-global-mensal $>$. Access on: 15 Nov. 2010.

GAUQUELIN, T. et al. Cycle biogéochimique et hétérogénéité édaphique des groupements forestiers pré-steppiques à Genévrier thurifère du Haut Atlas de Marrakech, Maroc. Revue de la Société Française d'Ecologie, v. 29, n. 1/2, p. 177-180, 1998.

GONZÁLEZ-RODRÍGUEZ, $H$. et al. Litterfall deposition and leaf litter nutrient return in different locations at northeastern Mexico. Plant Ecology, v. 212, p. 1747-1757, 2011.

GRIZ, L.M.S.; MACHADO, I.C.S. Fruiting phenology and seed dispersal syndromes in caatinga, a tropical dry forest in the northeast of Brazil. Journal of Tropical Ecology, v. 17, p. 303-321, 2001.

HOOKER, T.D.; STARK, J.M. Soil C and N cycling in three semiarid vegetation types: response to an in situ pulse of plant detritus. Soil Biology \& Biochemistry, v. 40, p. 2678-2685, 2008.

INSTITUTO NACIONAL DE METEOROLOGIA INMET. Gráficos climatológicos. Available at: $<$ http://www.inmet.gov.br/portal/index.php?r= clima/graficosClimaticos>. Access on: 12 Nov. 2010.

ISAAC, S.R.; NAIR, M.A. Litter dynamics of six multipurpose trees in a homegarden in southern Kerala, India. Agroforestry in Sustainable Agricultural Systems, v. 67, p. 203-213, 2006.

JHA, P.; MOHAPATRA, K.P. Leaf litterfall, fine root production and turnover in four major tree species of the semi-arid region of India. Plant and Soil, v. 326, p. 481-491, 2010.

LI, Y.; XU, M.; ZOU, X. Effects of nutrient additions on ecosystem carbon cycle in a Puerto Rican tropical wet forest. Global Change Biology, v. 12, p. 284-293, 2006.

LIMA, A.L.A.; RODAL, M.J.N. Phenology and wood density of plants growing in the semi-arid region of northeastern Brazil. Journal of Arid Environments, v. 74, p. 1363-1373, 2010.
LODHIYAL, N.; LODHIYAL, L.S. Pangtey YPS structure and function of shisham forests in central Himalaya, India: dry matter dynamics. Annals of Botany, v. 89, p. 41-54, 2002.

MARTÍNEZ-ALONSO, C. et al. The uncoupling of secondary growth, cone and litter production by intradecadal climatic variability in a Mediterranean Scots pine forest. Forest Ecology and Management, v. 253, p. 19-29, 2007.

McIVOR, J.G. Litterfall from trees in semiarid woodlands of north-east Queensland. Austral Ecology, v. 26, p. 150-155, 2001.

MEENTEMEYER, V.; BOX, E.O.; THOMPSON, R. World patterns and amounts of terrestrial plant litter production. BioScience, v. 32, p. 125-128, 1982.

MENEZES, B.S. Dinâmica espaço-temporal em um fragmento de savana decídua espinhosa, semi-árido do Brasil. 2010. 65 f. Dissertação (Mestrado em Ecologia e Recursos Naturais) Universidade Federal do Ceará, Fortaleza.

MONASTERIO, M.; SARMIENTO, G. Phenological strategies of plant species in the tropical savanna and the semi-deciduous forest of the Venezuelan Llanos. Journal of Biogeography, v. 3, p. 325-355, 1976.

MONTÈS, N. et al. Biomass and nutrient content of a semi-arid mountain ecosystem: the Juniperus thurifera L. woodland of Azzaden Valley (Morocco). Forest Ecology and Management, v. 166, n. 1-3, p. 35-43, 2002.

NAVARRO, F.B. et al. Effects of thinning on litterfall were found after years in a Pinus halepensis afforestation area at tree and stand levels. Forest Ecology and Management, v. 289, p. 354-362, 2013.

PEEL, M.C.; FINLAYSON, B.L.; McMAHON, T.A. Updated world map of the Köppen-Geiger climate classification. Hydrology and Earth System Sciences, v. 11, p. 1633-1644, 2007.

PROCTOR, J. et al. Ecological studies in four contrasting lowland rain forests in Gunung Mulu National Park, Sarawak. II. Litterfall, litter standing crop and preliminary observation on herbivory. Journal of Ecology, v. 71, p. 281-263, 1983. 
R DEVELOPMENT CORE TEAM. R: a language and environment for statistical computing. Vienna: R Foundation for Statistical Computing, 2010.

ROTHE, A.; BINKLEY, D. Nutritional interactions in mixed species forests: a synthesis. Canadian Journal of Forest Research, v. 31, p. 1855-1870, 2001.

SANTANA, J.A.S.; SOUZA, L.K.V.S.; ALMEIDA, W.C. Produção anual de serapilheira em Floresta Secundária na Amazônia Oriental. Revista Ciências Agrárias, v. 40, p. 119-132, 2003.

SANTOS, P.S. et al. Diferenças sazonais no aporte de serrapilheira em uma área de caatinga em Pernambuco. Revista Caatinga, v. 24, p. 94-101, 2011.

SHIPLEY, B.; MEZIANE, D. The balanced-growth hypothesis and the allometry of leaf and root biomass allocation. Functional Ecology, v. 16, p. 326-331, 2002.

SILVEIRA, A.P.; MARTINS, F.R.; ARAÚJO, F.S. Do vegetative and reproductive phenophases of deciduous tropical species respond similarly to rainfall pulses? Journal of Forestry Research, v. 24, p. 643-651, 2013.

SPAIN, A.V. Litterfall and the standing crop of litter in three tropical Australian rainforests. Journal of Ecology, v. 72, p. 947-961, 1984.

STAELENS, J. et al. A model of wind-influenced leaf litterfall in a mixed hardwood forest. Canadian Journal of Forest Research, v. 33, p. 201-209, 2003.

SUNDARAPANDIAN, S.M.; SWAMY, P.S. Litter production and leaf-litter decomposition of selected tree species in tropical forests at Kodayar in the Western Ghats, India. Forest Ecology and Management, v. 123, p. 231-244, 1999.

VASCONCELOS, H.L.; LUIZÃO, F.J. Litter production and litter nutrient concentrations in a fragmented Amazonian landscape. Ecological Applications, v. 14, p. 884-892, 2004.

WOODWARD, F.I.; LOMAS, M.R.; KELLY, C.K. Global climate and the distribution of plant biomes. Philosophical Transactions of the Royal Society B, v. 359, p. 1465-1476, 2004.
ZHOU, G. et al. Litterfall production along successional and altitudinal gradients of subtropical monsoon evergreen broadleaved forests in Guangdong, China. Plant Ecology, v. 188, p. 77-89, 2007.

ZIMMERMAN, J.K.; PASCARELLA, J.B.; AIDE, T.M. Barriers to forest regeneration in an abandoned pasture in Puerto Rico. Restoration Ecology, v. 8, n. 4 , p. $350-360,2000$. 